\title{
ANALISIS KESENJANGAN PERENCANAAN DAN PELAKSANAAN PEMBELAJARAN KURIKULUM 2013 DI SD NO. 4 BANYUASRI
}

\author{
I Wayan Adi Antara, Ndara Tanggu Renda \\ Jurusan Pendidikan Guru Sekolah Dasar, Fakultas Ilmu Pendidikan \\ Universitas Pendidikan Ganesha, Jln. Udayana No. 11 Singaraja \\ e-mail: wayanadiantara.id@gmail.com
}

\begin{abstract}
This study was aimed to (1) analyzed discrepancied the curriculum of 2013's lesson plan, that was created by teachers at SD No. 4 Banyuasri in the academic years 2015/2016 with Permendikbud Nomor 103 Tahun 2014; (2) analyzed discrepancied the learning process of curriculum 2013 by teachers at SD No. 4 Banyuasri in the academic years 2015/2016 with Permendikbud No. 103 Tahun 2014. The research is an evaluative research. The methods of collecting data was (1) documentation study, (2) observation, and (3) interviews. The data that have been collected were processed using non-parametric statistical test Wilcoxon, then continued with the presentation of the data and conclusions. The subjects of this study was all of the teachers in SD No. 4 Banyuasri. The object of the research is the lesson plan and the implementation of learning using the curriculum of 2013 who conceived and implemented by teachers based on Permendikbud No. 103 Tahun 2014. The results showed that (1) The size of the gap between lesson plan with curriculum 2013, that was created by teachers in SD No. 4 Banyuasri in the academic years 2015/2016 based on Permendikbud No. 103 Tahun 2014 was $15 \%$ and classified as a very small category, (2) The size of the gap between learning implementation in curriculum of 2013 that have been done by the teachers in SD No. 4 Banyuasri in the academic years 2015/2016 with Permendikbud No. 103 Tahun 2014 was $25,21 \%$ and classified as a small category.
\end{abstract}

Keywords: discrepancy, lesson plan, implementation of learning, Permendikbud No. 103/2014

\begin{abstract}
ABSTRAK: Penelitian ini bertujuan (1) untuk menganalisis kesenjangan rencana pelaksanaan pembelajaran Kurikulum 2013 yang dibuat oleh guru SD No. 4 Banyuasri Tahun Pelajaran 2015/2016 dengan Permendikbud Nomor 103 Tahun 2014 tentang Kurikulum 2013; (2) untuk menganalisis kesenjangan pelaksanaan pembelajaran Kurikulum 2013 yang dilakukan oleh guru SD No. 4 Banyuasri Tahun Pelajaran 2015/2016 dengan Permendikbud Nomor 103 Tahun 2014. Jenis penelitian ini adalah penelitian evaluatif. Pengumpulan data dalam penelitian ini dilakukan dengan metode (1) studi dokumentasi, (2) observasi, dan (3) wawancara. Data yang sudah terkumpul diolah dengan menggunakan statistik non parametrik dengan uji bertanda wilcoxon, kemudian dilanjutkan dengan penyajian data, dan penarikan kesimpulan. Subjek dalam penelitian ini yaitu seluruh guru kelas di SD No. 4 Banyuasri. Objek penelitian ini adalah RPP dan pelaksanaan pembelajaran dengan kurikulum 2013 yang disusun dan dilaksanakan oleh guru berdasarkan Permendikbud Nomor 103 Tahun 2014. Hasil penelitian menunjukkan bahwa (1) besarnya kesenjangan rencana pelaksanaan pembelajaran dengan Kurikulum 2013 yang dibuat oleh guru SD No. 4 Banyuasri Tahun Pelajaran 2015/2016 dengan Permendikbud Nomor 103 Tahun 2014 adalah sebesar 15\% dan tergolong kategori sangat kecil (SK), (2) besarnya kesenjangan pelaksanaan pembelajaran dengan Kurikulum 2013 yang dilakukan oleh guru SD No. 4 Banyuasri Tahun Pelajaran 2015/2016 dengan Permendikbud Nomor 103 Tahun 2014 adalah sebesar $25,21 \%$ dan tergolong kategori kecil (K).
\end{abstract}

Kata-kata kunci: kesenjangan, perencanaan pembelajaran, pelaksanaan pembelajaran, Permendikbud No. 103/2014. 
Pendidikan merupakan salah satu faktor yang sangat menentukan kualitas suatu bangsa. Kegagalan pendidikan berimplikasi pada gagalnya suatu bangsa, keberhasilan pendidikan juga secara otomatis membawa keberhasilan bangsa tersebut. pendidikan bagi suatu bangsa merupakan suatu kebutuhan mendasar yang harus dipenuhi untuk meningkatkan kualitas sumber daya manusia, karena sumber daya manusia yang berkualias merupakan salah satu faktor yang dapat menunjang kemajuan bangsa tersebut. Sumber daya yang berkualitas dapat berupa dari siswa, masyarakat, maupun dari guru. Hal ini terlihat dari tujuan dan fungsi dari pendidikan itu sendiri, khususnya dalam pendidikan nasional sebagaimana diatur dalam UU Nomor 20 Tahun 2003 tentang sistem pendidikan nasional pasal 3 menyatakan bahwa,

Pendidikan nasional berfungsi
mengembangkan kemampuan dan membentuk watak serta peradaban bangsa yang bermartabat dalam rangka mencerdaskan kehidupan bangsa, bertujuan untuk berkembangnya potensi peserta didik agar menjadi manusia yang beriman dan bertakwa kepada Tuhan Yang Maha Esa, berakhlak mulia, sehat, berilmu, cakap, kreatif, mandiri, dan menjadi warga negara yang demokratis serta bertanggung jawab.

Untuk mencapai tujuan pendidikan tersebut sangat ditentukan oleh beberapa komponen yang terpadu dan saling berkaitan satu dengan yang lain diantaranya kurikulum, tenaga ke pendidikan, peserta didik, sarana dan prasarana penunjang lainnya. Khususnya dalam pelaksanaan kurikulum sangat berpengaruh terhadap kualitas pendidikan itu sendiri. Berdasarkan Pasal 1 butir 19 UU Nomor 20 Tahun 2003 tentang sistem pendidikan nasional, "Kurikulum adalah seperangkat rencana, dan pengaturan mengenai tujuan, isi, dan bahan pelajaran serta cara yang digunakan sebagai pedoman penyelenggaraan kegiatan pembelajaran untuk mencapai tujuan pendidikan tertentu".

Mengingat pentingnya peranan kurikulum dalam pendidikan dan dalam perkembangan kehidupan manusia, penyusunan kurikulum tidak dapat dikerjakan sembarangan, terutama pada tahap pengembangannya. Untuk meningkatkan kualitas pendidikan di Indonesia, kurikulum selalu dikembangkan dan disempurnakan kembali. Sehingga dalam dunia pendidikan di Indonesia terjadi beberapa kali pergantian kurikulum. Kurniasih dan Sani (2014) mengemukakan perubahan kurikulum tersebut didasari pada kesadaran bahwa perkembangan perubahan yang terjadi menuntut perlunya perbaikan sistem pendidikan nasional termasuk penyempurnaan kurikulum untuk mewujudkan masyarakat yang mampu bersaing dan menyesuaikan diri dengan perubahan.

Salah satu faktor yang mendorong untuk mengembangkan kurikulum adalah amanat Undang-Undang tentang Sitem pendidikan Nasional. Kurikulum pertama di Indonesia telah lahir sebagai penjabaran amanat dalam Undang - Undang Nomor 4 Tahun 1950 tentang Dasar Dasar pendidikan dan Pengajaran, UndangUndang Nomor 12 Tahun 1954, UU Nomor 22 Tahun 1961, UU Nomor 2 Tahun 1989, dan akhirnya UU Nomor 20 Tahun 2003 tentang Sistem pendidikan Nasional. Di samping itu, tuntutan globalisasi, dan perkembangan ilmu pengetahuan dan teknolgi juga ikut mendorong terjadinya perbaikan dan pengembangan kurikulum. Sejak Indonesia merdeka sampai saat ini telah terjadi beberapa kali perubahan kurikulum.

Wirianto (2014) menyebutkan beberapa kurikulum yang berlaku di Indonesia diantaranya, Kurikulum 1947, Kurikulum 1968, Kurikulum 1975, Kurikulum 1984, Kurikulum 1994, Kurikulum 2004 (KBK), kurikulum 2006 (KTSP) dan yang terakhir adalah Kurikulum 2013.

Penerapan suatu kurikulum tentu disertai dengan suatu kebijakan yang nantinya akan menjadi pedoman atau acuan dalam pelaksanaan kurikulum tersebut. Kurikulum 2013 dilaksanakan berdasarkan landasan hukum yang telah dikeluarkan oleh Kementerian Pendidikan dan Kebudayaan. Berbagai Peraturan telah diterbitkan untuk menunjang pelaksanaan Kurikulum 2013. Salah satu Peraturan yang menjelaskan bagaimana pelaksanaan kurikulum 2013 yang menjadi acuan dalam pelaksanaan pembelajaran saat ini adalah Permendikbud Nomor 103 Tahun 2014 tentang pembelajaran pada pendidikan dasar dan menengah.

Guru yang profesional adalah guru yang memiliki seperangkat kompetensi (pengetahuan, keterampilan, dan prilaku) yang harus dimiliki, dihayati, dan dikuasai oleh guru dalam melaksanakan tugas keprofesionalannya (Syaefudin, 2008). Keberhasilan seorang guru 
menjadikan peserta didik yang sesuai dengan tujuan pendidikan nasional harus disertai dengan persiapan yang matang. Suparno (2002) mengemukakan, sebelum guru mengajar seorang guru diharapkan mempersiapkan bahan yang akan diajarkan. Perencanaan pembelajaran meliputi penyusunan RPP, penyiapan media dan sumber belajar, perangkat penilaian pembelajaran, dan skenario pembelajaran. Penyusunan RPP disesuaikan dengan pendekatan pembelajaran yang digunakan sebagaimana diatur dalam Permendikbud Nomor 103 Tahun 2014. Kemudian RPP yang telah dibuat nantinya akan diimplementasikan dalam proses pembelajaran dikelas. Proses pembelajaran sebagaimana diatur dalam Permendikbud No. 103 Tahun 2014 harus mempunyai karakteristik yaitu, interaktif dan inspiratif, menyenangkan, menantang, dan memotivasi peserta didik untuk berpartisipasi aktif, kontekstual dan kolaboratif, memberikan ruang yang cukup bagi prakarsa, kreativitas, dan kemandirian peserta didik, dan sesuai dengan bakat, minat, kemampuan, dan perkembangan fisik serta psikologis peserta didik. Pendekatan pembelajaran yang digunakan adalah pendekatan saintifik yang merupakan pengorganisasian pengalaman belajar dengan urutan yang logis yaitu, mengamati, menanya, mengumpulkan informasi, menalar, dan mengomunikasikan.

Perubahan-perubahan yang terjadi dalam kurikulum termasuk pedoman pelaksanaannya membuat guru sebagai pelaksana kurikulum tidak serta merta dapat beradaptasi dengan mudah. Perencanaan dan pelaksanaan pembelajaran yang dilakukan oleh guru kerap kali belum sesuai dengan standar kurikulum 2013 yang ditetapkan dalam Permendikbud Nomor 103 Tahun 2014, Banyak hambatan yang ditemukan guru dalam penerapan Kurikulum 2013, sehingga pembelajaran belum bisa berjalan sesuai dengan standar.

Berdasarkan hasil observasi dan wawancara yang dilakukan di SD No. 4 Banyuasri pada tanggal 7 Desember 2015 ditemukan beberapa kendala yang dirasakan oleh guru dalam penerapan pembelajaran dengan kurikulum 2013 yaitu, yang pertama guru masih belum bisa beradaptasi dengan sistem pada Kurikulum 2013 karena kurkulum 2013 merupakan sesuatu yang baru terutama untuk guru kelas 3 dan kelas 6 yang baru menerapkan kurikulum 2013 pada tahun pelajaran 2015/2016. Sehingga dalam pelaksanaannya masih belum dapat terlaksana secara maksimal walaupun dalam kenyataannya pembelajaran dapat berlangsung. Yang kedua, Guru dalam menyusun RPP masih sering mengalami kendala, terutama pada kegiatan inti dan penilaian, hal ini dikarenakan pengintegrasian berbagai mata pelajaran dalam satu pembelajaran. Kesuliatan yang dihadapi adalah pada pemilihan kegiatan pembelajaran agar siswa tersebut dapat memahami materi dengan baik dan juga masalah juga dialami ada penilaian yang begitu kompleks. Dalam pelaksanaan pembelajaran guru masih belum bisa melaksanakan pembelajaran yang dapat membuat siswa berpartisipasi aktif dalam pembelajaran seseperti yang diamanatkan dalam peraturan pemerintah tersebut. Menurut kepala sekolah SD No.4 Banyuasri, walaupun sekolah kami telah menerapkan kurikulum 2013 sejak awal penerapannya, namun dalam beberapa hal khususnya dalam pembelajaran. Guru-guru masih mengalami beberapa hambatan dalam penerapan pembelajaran dengan Kurikulum 2013. pembelajaran memang sudah dapat berjalan, namun dirasa belum maksimal sesuai dengan yang diharapkan oleh peraturan.

Berdasarkan hasil observasi dan wawancara tersebut, maka perlu dilaksanakan penelitian tentang penerapan kurikulum 2013 yang difokuskan dalam penyusunan dan pelaksanaan RPP yang disusun dan dilaksanakan oleh guru. Bagaimana pelaksanaan kurikulum 2013 dalam pelaksanaannya pada sekolah-sekolah yang menjadi pilot project seperti SD No. 4 Banyuasri, tentu sangat diperlukan untuk dilakukan analisis teknik dalam implementasi kurikulum tersebut. Penelitian yang dapat dilakukan yaitu dengan evaluasi program untuk mengetahui besar kesenjangan RPP dan pembelajaran yang dilakukan oleh guru di SD No. 4 Banyuasri dengan standar acuan yaitu Permendikbud Nomor 103 Tahun 2014. Agung (2014:27) jenis penelitian evaluasi dilakukan untuk melakukan penilaian terhadap pelaksanaan suatu kegiatan yang sedang berjalan, dalam rangka mencari umpan balik untuk memperbaiki suatu sistem. Jadi dengan penelitian ini keterlaksanaan program yang dimaksud yaitu keterlaksanaan kurikulum 2013, yang nantinya manjadi pertimbangan oleh pengambil keputusan dalam memperbaiki penerapan kurikulm 2013 agar kedepannya menjadi lebih baik lagi. 
Berdasarkan pemaparan di atas dan mengingat begitu pentingnya perencanaan dan proses pembelajaran, menjadi menarik untuk mengetahui kesenjangan perencanan dan pelaksanaan pembelajaran yang disusun dan dilaksanakan oleh guru di SD No. 4 Banyuasri dengan standar acuan yaitu Permendikbud No. 103 Tahun 2014 maka dilakukan penelitian yang berjudul "Analisis Kesenjangan Perencanaan Dan Pelaksanaan Pembelajaran Kurikulum 2013 Berdasarkan Permendikbud Nomor 103 Tahun 2014 di SD No. 4 Banyuasri Tahun Pelajaran 2015/2016".

Tujuan penelitian ini adalah sebagai berikut. 1) Untuk menganalisis kesenjangan Rencana Pelaksanaan Pembelajaran (RPP) Kurikulum 2013 yang dibuat oleh guru SD No. 4 Banyuasri Tahun Pelajaran 2015/2016 dengan Permendikbud Nomor 103 Tahun 2014 tentang Kurikulum 2013; 2) Untuk menganalisis kesenjangan pelaksanaan pembelajaran Kurikulum 2013 yang dilakukan oleh guru SD No. 4 Banyuasri Tahun Pelajaran 2015/2016 dengan Permendikbud Nomor 103 Tahun 2014 tentang Kurikulum 2013.

\section{METODE}

Berdasarkan tujuan dari penelitian ini yaitu untuk mengetahui kesenjangan antara perencanaan dan pelaksanaan pembelajaran kurikulum 2013 yang disusun dan dilaksanakan oleh guru SD No. 4 Banyuasri dengan Permendikbud No. 103 Tahun 2014, maka jenis penelitian yang digunakan adalah penelitian evaluatif. Sebagaimana dijelaskan oleh Kline (dalam Hadi dan Mutrofin, 2005:1) "Riset evaluasi dimaksudkan untuk mengukur hasil suatu kebijakan, program, proyek, produk, atau aktivitas tertentu". Senada dengan pendapat tersebut Agung (2014:27) penelitian evaluasi (evaluation research) merupakan jenis penelitian yang dilakukan untuk menilai keterlaksanaan suatu kegiatan yang sedang berjalan, dalam rangka umpan balik untuk perbaikan suatu sistem. penelitian evaluatif yang digunakan adalah model kesenjangan (diskrepancy modeI). Model ini dikembangkan oleh Malcom Provus

Subjek dari penelitian ini adalah Permendikbud No 103 Tahun 2014 tentang Kurikulum 2013 dan guru kelas 1 sampai kelas 6 di SD N 4 Banyuasri.

Objek penelitian ini adalah rencana pelaksanaan pembelajaran dan pelaksanaan pembelajaran yang dibuat dan dilaksanakan oleh guru di SD No. 4 Banyuasri.

Instrumen dalam penelitian ini berupa lembar studi dokumentasi dan lembar observasi dikembangkan oleh peneliti. Sebelum instrumen ini digunakan maka diteliti dulu kualitasnya. Kualitas instrumen ditunjukkan oleh kesahihan (validitas) dalam mengungkapkan apa yang akan diukur. Lembar studi dokumentasi diperoleh koefisien validitas isi sebesar 1,00, ini menunjukkan bahwa Lembar studi dokumentasi memiliki validitas isi yang tinggi; lembar observasi diperoleh koefisien validitas isi sebesar 1,00, ini menunjukkan bahwa lembar observasi memiliki validitas isi yang tinggi. Oleh karena semua instrumen penelitian dikatakan valid dari segi validitas isi maka instrumen ini sudah boleh untuk digunakan dilapangan.

Tabel 1. Kriteria Acuan Diskrepansi (Kesenjangan)

\begin{tabular}{ll}
\hline Besar Beda dengan Acuan (Standar) $\%$ & Kategori Kesenjangan \\
\hline $\mathrm{D}=0 \%$ & Tanpa Kesenjangan \\
\hline $0 \%<\mathrm{D} \leq 20 \%$ & Sangat Kecil \\
\hline $20 \%<\mathrm{D} \leq 40 \%$ & Kecil \\
\hline $40 \%<\mathrm{D} \leq 60 \%$ & Cukup Besar \\
\hline $60 \%<\mathrm{D} \leq 80 \%$ & Besar \\
\hline $80 \%<\mathrm{D} \leq 100 \%$ & Sangat Besar \\
\hline
\end{tabular}

(Sumber: dimodifikasi dari Sudarma, 2011)

Analisis data yang digunakan dalam penelitian ini adalah statistik non parametrik yaitu uji jenjang bertanda wilcoxon. Uji jenjang bertanda Wilcoxon bertujuan untuk mengetahui apakah terdapat perbedaan nyata antara standar acuan dengan pelaksanaan standar proses oleh 
guru pada satuan pendidikan dan kesenjangan tersebut dikonversikan dalam kategori berdasarkan Tabel 1.

\section{HASIL DAN PEMBAHASAN}

Hasil
Berdasarkaan observasi dan studi dokumentasi serta dilanjutkan dengan analisis data yang dilakukan diperoleh data kesenjangan perencanaan dan pelaksanaan pembelajaran yang disajikan pada Tabel 2 .

Tabel 2. Rekapitulasi Hasil Analisis Diskrepansi Perencanaan dan Pelaksanaan Pembelajaran Pada Masing-Masing Guru

\begin{tabular}{|c|c|c|c|c|c|c|c|c|c|c|}
\hline \multicolumn{2}{|c|}{ Responden } & \multicolumn{9}{|c|}{ Pembelajaran Berdasarkan Permendikbud No. 103 Tahun 2014} \\
\hline \multirow[t]{2}{*}{ No. } & \multirow[t]{2}{*}{ Kelas } & & \multicolumn{4}{|c|}{ Perencanaan Pembelajaran } & \multicolumn{4}{|c|}{ Pelaksanaan Pembelajaran } \\
\hline & & $\begin{array}{l}\text { Stan-dar } \\
\text { (X) }\end{array}$ & $\begin{array}{l}\text { Skor } \\
\text { (Y1) }\end{array}$ & $\begin{array}{l}\text { Tanda } \\
\text { Beda }\end{array}$ & $\begin{array}{l}\text { Besar } \\
\text { Beda }\end{array}$ & Kategori & $\begin{array}{l}\text { Skor } \\
(\mathrm{Y} 2)\end{array}$ & $\begin{array}{c}\text { Tanda } \\
\text { Beda }\end{array}$ & $\begin{array}{l}\text { Besar } \\
\text { Beda }\end{array}$ & Kategori \\
\hline 1 & 1 & 100 & 82 & - & -18 & SK & 82.5 & - & -17.5 & SK \\
\hline 2 & 2 & 100 & 86 & - & -14 & SK & 70.0 & - & -30.0 & K \\
\hline 3 & 3 & 100 & 87 & - & -13 & SK & 85.0 & - & -15.0 & SK \\
\hline 4 & 4 & 100 & 88 & - & -12 & SK & 72.5 & - & -27.5 & $\mathrm{~K}$ \\
\hline 5 & 5 & 100 & 89 & - & -11 & SK & 66.25 & - & -33.75 & K \\
\hline 6 & 6 & 100 & 78 & - & -22 & $\mathrm{~K}$ & 72.5 & - & -27.5 & $\mathrm{~K}$ \\
\hline & & 600 & 510 & - & -90 & & 448.8 & - & -151.3 & \\
\hline & & 100 & 85 & - & -15 & SK & 74.79 & - & -25.21 & K \\
\hline
\end{tabular}

Berdasarkan rekapitulasi analisis diskrepansi perencanaan pembelajaran pada masing-masing guru pada Tabel 2, diperoleh besar beda -15 dan tergolong kategori sangat kecil (SK) sehingga dapat dikatakan bahwa kondisi riil belum mencapai standar atau kondisi ideal yang ditetapkan. Jika dilihat per guru, guru yang memperoleh skor tertinggi adalah G5 dengan skor 89 dan besar beda -11 tergolong kategori sangat kecil (SK). Guru yang memperoleh skor terendah adalah G6 yang memperoleh skor 78 dengan besar beda -22 tergolong dalam kategori kecil (K).
Pelaksanan pembelajaran pada masingmasing guru pada Tabel 2, diperoleh besar beda -25,21 dan tergolong kategori kecil (K). Guru yang memperoleh skor tertinggi adalah G3 dengan skor 85 dan besar beda -15 tergolong kategori sangat kecil (SK). Guru yang memperoleh skor terendah adalah G5 yang memperoleh skor 6,25 dengan besar beda 33,75 tergolong dalam kategori kecil (K).

Selain dianalisis dari masing-masing guru perencanaan dan pelaksanaan pembelajaran juga dianalisis pada setiap komponen atau butir instrumen. Hasil analisis diskrepansi pada setiap komponen disajikan pada Tabel 3 dan Tabel 4.

Tabel 3. Rekapitulasi Hasil Analisis Diskrepansi Perencanaan Pembelajaran Pada Setiap Komponen

\begin{tabular}{|c|c|c|c|c|c|c|}
\hline \multicolumn{7}{|c|}{ Perencanaan Pemberalajaran } \\
\hline $\begin{array}{l}\text { No } \\
\text { Butir }\end{array}$ & Standar & Skor & $\begin{array}{l}\text { Tanda } \\
\text { Beda }\end{array}$ & $\begin{array}{l}\text { Besar } \\
\text { Beda }\end{array}$ & $\begin{array}{c}\text { Persentase Besar } \\
\text { Beda }(\%)\end{array}$ & Kategori \\
\hline 1 & 100 & 100 & & 0 & 0 & TK \\
\hline 2 & 100 & 100 & & 0 & 0 & TK \\
\hline 3 & 100 & 100 & & 0 & 0 & TK \\
\hline 4 & 100 & 100 & & 0 & 0 & TK \\
\hline 5 & 100 & 100 & & 0 & 0 & TK \\
\hline 6 & 100 & 100 & & 0 & 0 & TK \\
\hline 7 & 100 & 93,33 & - & $-6,67$ & 6,67 & SK \\
\hline
\end{tabular}




\begin{tabular}{|c|c|c|c|c|c|c|}
\hline \multicolumn{7}{|c|}{ Perencanaan Pemberalajaran } \\
\hline $\begin{array}{l}\text { No } \\
\text { Butir }\end{array}$ & Standar & Skor & $\begin{array}{l}\text { Tanda } \\
\text { Beda }\end{array}$ & $\begin{array}{l}\text { Besar } \\
\text { Beda }\end{array}$ & $\begin{array}{c}\text { Persentase Besar } \\
\text { Beda }(\%)\end{array}$ & Kategori \\
\hline 8 & 100 & 83,33 & - & $-16,67$ & 16,67 & SK \\
\hline 9 & 100 & 70 & - & -30 & 30 & $\mathrm{~K}$ \\
\hline 10 & 100 & 60 & - & -40 & 40 & $\mathrm{~K}$ \\
\hline 11 & 100 & 70 & - & -30 & 30 & $\mathrm{~K}$ \\
\hline 12 & 100 & 96,67 & - & $-3,33$ & 3,33 & SK \\
\hline 13 & 100 & 76,67 & - & $-23,33$ & 23,33 & $\mathrm{~K}$ \\
\hline 14 & 100 & 63,33 & - & $-36,67$ & 36,67 & $\mathrm{~K}$ \\
\hline 15 & 100 & 86,67 & - & $-13,33$ & 13,33 & SK \\
\hline 16 & 100 & 96,67 & - & $-3,33$ & 3,33 & SK \\
\hline 17 & 100 & 80 & - & -20 & 20 & SK \\
\hline 18 & 100 & 83,33 & - & $-16,67$ & 16,67 & SK \\
\hline 19 & 100 & 66,67 & - & $-33,33$ & 33,33 & $\mathrm{~K}$ \\
\hline 20 & 100 & 73,33 & - & $-26,67$ & 26,67 & $\mathrm{~K}$ \\
\hline Jumlah & 2000 & 1700 & - & -300 & 300 & \\
\hline Rerata & 100 & 85 & - & -15 & 15 & SK \\
\hline
\end{tabular}

Dilihat dari besar kesenjangannya butir nomor 10 dengan indikator materi pembelajaran ditulis dalam bentuk butir-butir sesuai dengan rumusan indikator pencapaian kompetensi, merupakan butir yang mengalami kesenjangan tertinggi dengan kesenjangan sebesar $40 \%$ dengan kategori kecil (K). Kesenjangan ini akibat dari kebanyakan guru tidak menulis materi pembelajaran dalam bentuk butir-butir sesuai dengan rumusan indikator, hanya dicantumkan judul-judul materinya saja.

Kemudian hasil analisis kesenjangan pelaksanaan pembelajaran pada masing-masing indikator pada pelaksanaan pembelajaran yang sesuai dengan Permendikbud Nomor 103 Tahun 2014 terlihat pada Tabel 4.

Tabel 4. Rekapitulasi Hasil Analisis Diskrepansi Pelaksanaan Pembelajaran Pada Setiap Komponen

\begin{tabular}{ccccccc}
\hline \multicolumn{7}{c}{ Pelaksanaan Pemberalajaran } \\
$\begin{array}{c}\text { No } \\
\text { Butir }\end{array}$ & Standar & Skor & $\begin{array}{c}\text { tanda } \\
\text { beda }\end{array}$ & $\begin{array}{c}\text { Besar } \\
\text { Beda }\end{array}$ & $\begin{array}{c}\text { persentase besar } \\
\text { beda }(\%)\end{array}$ & Kategori \\
\hline 1 & 100 & 73,33 & - & $-26,67$ & 26,67 & $\mathrm{~K}$ \\
\hline 2 & 100 & 70 & - & -30 & 30 & $\mathrm{~K}$ \\
\hline 3 & 100 & 66,67 & - & $-33,33$ & 33,33 & $\mathrm{~K}$ \\
\hline 4 & 100 & 80 & - & -20 & 20 & SK \\
\hline 5 & 100 & 60 & - & -40 & 40 & $\mathrm{~K}$ \\
\hline 6 & 100 & 73,33 & - & $-26,67$ & 26,67 & $\mathrm{~K}$ \\
\hline 7 & 100 & 86,67 & - & $-13,33$ & 13,33 & SK \\
\hline 8 & 100 & 100 & & 0 & 0 & TK \\
\hline 9 & 100 & 70 & - & -30 & 30 & $\mathrm{~K}$ \\
\hline 10 & 100 & 93,33 & - & $-6,67$ & 6,67 & SK \\
\hline 11 & 100 & 90 & - & -10 & 10 & SK \\
\hline
\end{tabular}




\begin{tabular}{ccccccc}
\hline \multicolumn{7}{c}{ Pelaksanaan Pemberalajaran } \\
\hline $\begin{array}{c}\text { No } \\
\text { Butir }\end{array}$ & Standar & Skor & $\begin{array}{c}\text { tanda } \\
\text { beda }\end{array}$ & $\begin{array}{c}\text { Besar } \\
\text { Beda }\end{array}$ & $\begin{array}{c}\text { persentase besar } \\
\text { beda }(\%)\end{array}$ & Kategori \\
\hline 12 & 100 & 73,33 & - & $-26,67$ & 26,67 & $\mathrm{~K}$ \\
\hline 13 & 100 & 63,33 & - & $-36,67$ & 36,67 & $\mathrm{~K}$ \\
\hline 14 & 100 & 80 & - & $-20,00$ & 20 & SK \\
\hline 15 & 100 & 60 & - & $-40,00$ & 40 & $\mathrm{~K}$ \\
\hline 16 & 100 & 56,67 & - & $-43,33$ & 43,33 & $\mathrm{CB}$ \\
\hline Jumlah & 1600 & 1196,67 & - & $-403,33$ & 403,33 & \\
\hline Rerata & 100 & 74,79 & - & $-25,21$ & 25,21 & $\mathrm{~K}$ \\
\hline
\end{tabular}

Berdasarkan tabel tersebut terlihat bahwa kesenjangan yang tertinggi terletak pada butir nomor 16 yaitu dengan indikator pendidik menyampaikan rencana pembelajaran pada pertemuan berikutnya, dengan besar kesenjangan sebesar $43,33 \%$ dan tergolong dalam kategori cukup besar (CB).

\section{Pembahasan}

Berikut pemaparan kesenjangan perencanaan dan pelaksanaan pembelajaran dengan kurikulum 2013 berdasarkan Permendikbud Nomor 103 Tahun 2014 di SD No. 4 Banyuasri.

Kesenjangan terletak pada komponen Kompetensi dasar Dalam Permendikbud Nomor 103 Tahun 2014 dalam penyusunan RPP, kompetensi dasar harus memuat secara utuh kompetensi dasar sikap spriritual (KD dari KI1), sosial (KD dari KI-2), pengetahuan (KD dari KI-3), dan keterampilan (KD dari KI-4). Namun dalam kenyataan di lapangan, beberapa guru di SD No. 4 Banyuasri yaitu Guru kelas 2 hanya memuat kompetensi dasar dari KI-3 dan KI-4 saja. Hal tersebut tentu tidak sesuai dengan Permendikbud Nomor 103 Tahun 2014 yang menuntut dalam kompetensi dasar harus memuat secara utuh $\mathrm{KD}$ dari $\mathrm{KI}-1$ sampai $\mathrm{KD}$ dari KI-4.

Kesenjangan pada subkomponen indikator pencapaian kompetensi dengan indikator mencantumkan indikator pencapaian kompetensi dan dirumuskan berdasarkan kompetensi dasar. Dalam Permendikbud Nomor 103 Tahun 2014 dalam RPP komponen indikator pencapaian kompetensi harus memuat indikator dari masing-masing kompetensi dasar, mulai dari KD dari KI-1 sampai KD dari KI-4 dan penyusunannya harus disesuaikan dengan kompetensi dasar yang hendak dicapai. Namun, berdasarkan studi dokumentasi yang dilakukan ditemukan bahwa beberapa guru yaitu guru kelas 1, kelas 2, dan guru kelas 3 hanya memuat indikator dari KD dari KI-3 dan KD dari KI-4.

Kesenjangan berikutnya ditemukan dalam RPP yang disusun oleh seluruh guru di SD No. 4 Banyuasri yaitu pada subkomponen materi pembelajaran. Permendikbud Nomor 103 Tahun 2014 menghendaki dalam RPP kurikulum 2013 harus memuat fakta, konsep, prinsip, dan prosedur yang relevan. Selain itu dalam Permendikbud Nomor 103 Tahun 2014 juga menghendaki materi pembelajaran ditulis dalam bentuk butir-butir sesuai dengan rumusan indikator pencapaian kompetensi.

Pada indikator kegiatan pembelajaran sesuai dengan pendekatan saintifik dan menggunakan model pembelajaran yang inovatif dan subkomponen kegiatan pembelajaran yang dirancang menjadikan lingkungan sekitarnya sebagai sumber belajar. masih menggunakan model pembelajaran yang kurang inovatif.

kesenjangan pada subkomponen menjadikan lingkungan sekitar sebagai sumber belajar, beberapa RPP yang disusun masih belum menjadikan lingkungan sekitar sebagai sumber belajar. Dalam Permendikbud Nomor 103 Tahun 2014 guru hendaknya memanfaatkan lingkungan sekitar sebagai sumber belajar secara optimal guna menunjang pembelajaran yang kontekstual dimana siswa belajar dengan lingkungan yang ada di sekitarnya.

Kesenjangan dalam subkomponen kegiatan pembelajaran juga terdapat dalam indikator memfasilitasi peserta didik untuk belajar secara mandiri karena pembelajaran lebih banyak diarahkan pada pembelajaran berdiskusi atau kelompok, kemandirian belajar 
diarahkan pada kegiatan menjawab pertanyaan yang ada dalam buku siswa.

Pada indikator memuat rancangan program pemberian umpan balik positif dan penguatan beberapa RPP masih terdapat kesenjangan atau belum sesuai maksimal dengan Permendikbud Nomor 103 Tahun 2014 kesenjangan tersebut terdapat dalam RPP yang disusun oleh guru kelas 1, kelas 4, kelas 5, dan kelas 6 berdasarkan wawancara dengan guru yang bersangkutan, untuk program pemberian umpan balik dilakukan situasional pada saat pembelajaran berlangsung sehingga dalam RPP tidak dicantumkan secara lengkap.

Kemudian pada indikator alokasi waktu pada masing-masing kegiatan pembelajaran, RPP yang disusun oleh para guru di SD No.4 banyuasri telah mendekati sesuai dengan standar Permendikbud Nomor 103 Taun 2014. Hanya saja ada 1 RPP yang disusun oleh Guru kelas 6 yag alokasi yang direncanakan tidak sesuai antara alokasi waktu yang terdapat dalam identitas RPP dengan alokasi waktu pada komponen kegiatan pembelajaran.

Kesenjangan juga terdapat pada subkomponen penilaian hasil belajar. Pada subkomponen penialaian hasil belajar ditemukan beberapa kesenjangan, yang mana kesenjangan tersebut berdasarkan studi dokumentasi terdapat pada RPP yang disusun oleh guru kelas 1, kelas 3, dan guru kelas 6 . Kesenjangan tersebut terjadi karena RPP yang disusun guru tersebut tidak mencantumkan kegiatan pembelajaran remidial dan pengayaan terhadap hasil belajar yang diperoleh siswa. Karena dalam Permendikbud Nomor 103 Tahun 2014 menghendaki bahwa pada RPP harus secara lengkap mencantumkan penilaian hasil belajar dari teknik penilaian, instruen penilaian, pembelajaran remidial dan pengayaan.

Kesenjangan juga terdapat dalam penulisan RPP pada subkomponen media dan sumber belajar. Pada subkomponen media dan sumber belajar ditemukan beberapa kesenjangan. Kesenjangan yang pertama terdapat pada indikator mencantumkan media pembelajaran yang dapat membantu guru dalam menyampaikan materi pembelajaran. Kesenjangan tersebut ditemukan pada RPP yang disusun oleh guru kelas 3, kelas 4, kelas 5, dan kelas 6. Dalam RPP yang disusun tersebut kurang lengkap mencantumkan media pembelajaran yang akan digunakan. memang sudah dicantumkan namun kurang lengkap mengenai inforasi mdiayang akan digunakan.

Kesenjangan dalam subkomponen media dan sumber belajar juga terdapat pada indikator mecantumkan sumber belajar yang dapat berupa buku, media cetak dan elektronik, alam sekitar dan sumber lain yang relevan. Kesenjangan tersebut ditemukan dalam RPP dari semua guru di SD No. 4 Banyuasri, dimana kesenjangan tersebut terjadi karena sumber belajar yang dicantumkan dalam RPP yang disusun oleh guru tersebut kurang lengkap. Hal tersebut kurang sesuai dengan amanat Permendikbud Nomor 103 Tahun 2014, dimana peraturan tersebut mengamanatkan untuk mencantumkan sumber belajar dengan jelas. baik sumber belajar tersebut dari buku, media cetak, dan elektronik, alam sekitar dan sumber belajar lainnya yang relevan.

Secara keseluruhan melihat dari hasil analisis data, dimana diperoleh besar kesenjangan antara perencanaan pembelajaran yang disusun oleh guru berdasarkan perencanaan perbelajaran sebagaimana diamanatkan dalam Permendikbud Nomor 103 tahun 2014 yaitu sebesar 15\%, jika dikonversikan dalam kategori maka kesenjangan tersebut tergolong sangat kecil (SK).

Kesenjangan-kesenjangan

yang ditemukan dalam penelitian ini sejalan dengan kesenjangan yang ditemukan pada penelitian tentang penyusunan perencanaan pembelajaran sebelumnya yaitu penelitian yang dilaksanakan oleh Sadewi. Kesenjngan yang sejalan tersebut diantaranya (1) pendidik hanya mencantumkan butir-butir materi tanpa memaparkan butir-butir tersebut baik berupa fakta, konsep, prinsip, maupun prosedur yang relevan; serta (2) langkah-langkah pembelajaran belum menggambarkan pembelajaran dengan pendekatan saintifik.

Wujud dari suatu evaluasi program tersebut adalah adanya suatu rekomendasi dari evaluator terhadap objek yang diteliti guna pengambilan keputusan (Arikunto, 2008). Melihat dari besar kesenjangan tersebut yang tergolong sangat kecil, oleh karena itu perencanaan pembelajaran yang disusun oleh guru di SD No. 4 Banyuasri sudah cukup baik dan layak untuk diteruskan meskipun masih terdapat beberapa komponen dalam RPP yang belum sesuai dengan standar acuan yakni Permendikbud Nomor 103 Tahun 2014. Tentunya dengan perbaikan-perbaikan pada 
aspek-aspek atau komponen dari RPP yang belum sesuai standar acuan.

Kemudian pada variabel pelaksanaan pembelajaran terdapat beberapa kesenjangan yaitu pada indikator mengondisikan kelas, beberapa guru yakni guru kelas 1, kelas 2, kelas 4, kelas 5 dan kelas 6 belum sepenuhnya menyiapkan suasana belajar yang membuat siswa siap mengikuti pembelajaran. Keterlaksnaan guru dalam mengondisikan kelas agar siswa siap dalam mengikuti pembelajaran sebesar $73,33 \%$, mengapa kesenjangan tersebut terjadi karena guru tidak memberikan motivasi kepada peserta didik. Beberapa guru yang bersangkutan hanya mengajak siswa untuk berdoa, menanyakan kabar siswa, melakukan absensi, dan mengatur tempat duduk.

Kemudian kesenjangan yang terdapat pada indikator menyampaikan apersepsi, beberapa guru yakni guru kelas 1, kelas 2, kelas 4, kelas 5, dan kelas 6 belum sepenuhnya menyampaikan apersepsi yang mengaitkan antara kompetensi yang telah dipelajari sebelumnya dengan kompetensi yang akan dipelajari, bahkan hasil observasi menunjukkan bahwa guru kelas 5 tidak memberikan apersepsi. Berdasarkan wawancara yang dilakukan dengan guru kelas 1, 2, 4, dan 6 mengapa guru tidak menyampaikan apersepsi dengan lengkap, itu dikarenakan keterbatasan waktu dibandingkan dengan materi yang begitu kompleks. Kemudian berdasarkan wawancara dengan guru kelas 5 mengapa beliau tidak menyampaikan apersepsi karena materi dan kegiatan pembelajaran tersebut merupakan lanjutan dari pertemuan sebelumnya.

Kemudian kesenjangan pada subkomponen kegiatan pendahuluan juga terdapat pada indikator menyampaikan kompetensi yang akan dicapai dan manfatnya dalam kehidupan sehari-hari. Kesenjangan tersebut berdasarkan hasil observasi yang dilakukan ditemukan pada semua guru, hal itu dikarenakan para guru belum sepenuhnya menyampaikan kompetensi yang akan dicapai sebagaimana yang telah dicantumkan dalam RPP dan juga manfatnya dalam kehidupan sehari-hari, berdasarkan wawancara dengan guru-guru yang bersangkutan, hal tersebut dikarenakan karena keterbatasan waktu dengan kompetensi yang begitu banyak dari masingmasing muatan pelajaran. Sehingga hanya beberapa poin saja yang disampaikan.
Kesenjangan juga terdapat pada indikator menyampaikan garis besar cakupan materi dan kegiatan yang dilakukan, kesenjangan pada indikator ini ditemukan pada semua guru. Pada indikator ini beberapa guru belum sepenuhnya atau kurang lengkap dalam menyampaikan garis besar cakupan materi.

Pada subkomponen kegiatan inti ditemukan beberapa kesenjangan. Kesenjangan tersebut terdapat pada beberapa indikator yakni yang pertama guru belum sepenuhnya menerapkan pembelajaran yang dilaksanakan secara interaktif, inspiratif, menyenangkan, menantang, memotivasi peserta didik untuk berpartisipasi aktif dalam proses pembelajaran. Berdasarkan hasil observasi guru-guru belum dapat membuat peserta didik untuk aktif dalam proses pembelajaran terlihat hanya beberapa siswa yang aktif. Kesenjangan ini ditemukan pada guru kelas 2, 4, 5, dan kelas 6 .

Kesenjangan juga terdapat dalam indikator guru senantiasa memperhatikan perkembangan sikap peserta didik pada kompetensi dasar dari KI-1 dan KI-2 (antara lain mensyukuri karunia Tuhan, jujur, teliti, kerjasama, toleransi, disiplin, taat aturan, dan menghargai pendapat) berdasarkan hasil observasi beberapa guru sudah memperhatikan dan mengingatkan kepada peserta didik tentang penerapan KD dari KI-1 dan KI-2, namun belum sepenuhnya sikap-sikap yang disebutkan diatas menjadi perhatian guru. Dimana kesenjangan tersebut ditemukan pada semua guru.

Kemudian kesenjangan juga terdapat pada indikator melakukan penilaian terhadap KD dari KI-4 yakni penilaian keterampilan. Guru sudah hampir semua melaksanakan penilaian keterampilan peserta didik namun pada guru kelas 4 dan kelas 6 belum sepenuhnya melakssanakannya. Jika melihat hasil analisis data bahwa kegiatan inti yang dilaksanakan guru di SD No. 4 Banyuasri sudah mendekati sesuai, hanya beberapa indikator masih terdapat kesenjangan dengan Permendikbud Nomor 103 Tahun 2014.

Pada subkomponen kegiatan penutup juga ditemukan kesenjangan, kesenjangan tersebut ditemukan pada beberapa indikator. Kesenjangan yang pertama pada indikator peserta didik diarahkan untuk membuat rangkuman/kesimpulan pelajaran pada indikator ini guru memang sudah melaksnakannya namun dalam beberapa guru belum sepenuhnya 
mengajak siswa membuat simpulan secara lengkap.

Kemudian kesenjangan yang kedua pada indikator peserta didik diarahkan untuk melakukan refleksi terhadap kegiatan yang sudah dilaksnakan. Beberapa guru masih kurang mengajak siswa untuk merefleksi kegiatan pembelajaran. Kesenjangan tersebut terdapat pada guru kelas 1, 2, 4, dan guru kelas 5. Guru yang bersangkutan belum sepenuhnya merefleksi kembali kegiatan-kegiatan yang sudah berlangsung, apakah peserta didik nyaman dan senang terhadap kegiatan yang telah dilaksanakan, dan merefleksi apa saja yang belum dipahami siswa.

Kesenjangan selanjutnya juga ditemukan pada indikator guru merencanakan kegiatan tindak lanjut dalam bentuk pembelajaran remidi, program pengayaan, layanan konseling, dan/atau memberikan tugas baik tugas individual maupun kelompok sesuai dengan hasil belajar peserta didik. Kesenjangan ini ditemukan pada semua guru hal ini dikarenakan tidak semua guru melaksanakannya secara lengkap. Berdasarkan observasi hal tersebut terjadi karena dalam melakukan penilalian hasil belajar waktu yang diperlukan cukup lama yang diperlukan siswa dan untuk membahas hasil dari penilaian tersebut sehingga waktu pembelajaran sudah hampir habis dan berakibat waktu yang tersedia untuk melakuan tindak lanjut hasil belajar siswa menjadi sedikit dan hanya diberikan tugas pekerjaan rumah. Hal itu tentu kurang sesuai dengan amanat dari Permendikbud Nomor 103 Tahun 2014 yang menghendaki pemberian tindak lanjut secara lengkap dari pemberian remidal, layanan konseling hingga pengayaan.

Pada indikator guru menyampaikan rencana pembelajaran pada pertemuan berikutnya juga ditemukan kesenjangan. Kesenjangan tersebut ditemukan pada semua guru. Hal ini dikarenakan keterbatasa waktu yang tersedia guru hanya menyampaikan materi apa-apa saja yang akan dipelajari pada pertemuan berikutnya.

Melihat dari hasil analisis data pada setiap komponen menunjukkan bahwa perolehan ratarata skor pelaksanaan pembelajaran sebesar 74,79 sehingga terdapat kesenjangan sebesar $25,21 \%$ dan tergolong dalam kategori kecil (K). Ketercapaian pelaksanaan pembelajaran yang dilakukan oleh guru di SD No. 4 banyuasri belum tercapai secara optimal sesuai dengan amanat Permendikbud Nomor 103 Tahun 2014.

Kesenjangan-kesenjangan

yang

ditemukan dalam penelitian ini sejalan dengan kesenjangan yang ditemukan pada penelitian tentang pelaksanaan pembelajaran sebelumnya yaitu penelitian yang dilaksanakan oleh Sadewi. Kesenjangan yang sejalan tersebut diantaranya (1) belum optimalnya penggunaan media; (3) belum adanya pemberian umpan balik; (3) belum adanya pemberian tindak lanjut berupa tugas kelompok; dan (4) belum adanya penyampaian materi pada pertemuan selanjutnya.

Melihat dari hasil observasi yang dilakukan dan dilanjutkan dengan analisis data yang menunjukkan kesenjangan sebesar 25,21\% dan tergolong dalam Kategori kecil (K). Oleh karena itu, pelaksanaan pembelajaran yang telah dilaksnakan oleh guru di SD No. 4 Banyuasri layak untuk diteruskan dengan beberapa perbaikan pada beberapa aspek atau komponen pembelajaran yang belum sesuai dengan amanat Permendikbud No 103 Tahun 2014.

\section{SIMPULAN}

Berdasarkan hasil analisis data dan pembahasan dapat disimpulkan hal-hal sebagai berikut yang pertama besarnya kesenjangan perencanaan pembelajaran dengan Kurikulum 2013 yang dibuat oleh guru SD No. 4 Banyuasri Tahun Pelajaran 2015/2016 dengan Permendikbud Nomor 103 Tahun 2014 adalah sebesar 15\% dan tergolong kategori sangat kecil (SK). Yang kedua besarnya kesenjangan pelaksanaan pembelajaran dengan Kurikulum 2013 yang dilakukan oleh guru SD No. 4 Banyuasri Tahun Pelajaran 2015/2016 dengan Permendikbud Nomor 103 Tahun 2014 adalah sebesar 25,21\% dan tergolong kategori kecil (K).

Saran-saran hal yang direkomendasikan adalah 1) pemerintah hendaknya melibatkan para guru yang merupakan pelaku utama dalam penerapan pembelajaran disatuan pendidikan, 2) pemerintah hendaknya lebih mengintensifkan sosialisasi terkait pembelajaran yang sesuai standar kepada guru melalui berbagai kegiatan pelatihan, workshop, seminar, lokakarya, serta kegiatan lain yang dapat melibatkan semua pihak yang terlibat langsung dalam pendidikan seperti guru, kepala satuan pendidikan, pengawas satuan pendidikan dan instansi terkait 
tentang penyusunan RPP dan lebih ditekankan pada komponen kompetensi dasar, indikator, materi pembelajaran, kegiatan pembelajaran, dan penilaian hasil belajar siswa serta penggunaan media. Tentang pelaksanaan pembelajaran dan lebih ditekankan pada komponen kegiatan pendahuluan, penilaian dan pembelajaran tindak lanjut dan yang paling penting adalah pengalokasian waktu, 3) Guru hendaknya selalu bersikap adaptif terhadap perubahan-perubahan yang terjadi dalam Kurikulum dan Peraturan-peraturan atau acuan dan meningkatkan kemampuannya dalam mengimplementasikan kurikulum 2013 dengan mengikuti berbagai kegiatan seperti pelatihan KKG, dan kegiatan lainnya, 4) kepala sekolah hendaknya selalu mengawasai kinerja dari bawahannya dan menginstruksikan kepada bawahannya untuk selalu mengembangkan kemampuannya dalam menyusun RPP dan melaksanakan pembelajaran dengan mengikuti kegiatan-kegiatan seperti Pelatihan, KKG, workshop, dan kegiatan terkait lainnya, dan 5) penelitian tentang evaluasi terhadap implementasi pembelajaran dengan kurikulum 2013 hendaknya lebih ditingkatkan lagi lebih luas cakupan satuan pendidikannya, untuk mengetahui apakah masih terdapat kesenjangan-kesenjangan dalam perencanaan dan pelaksanaan pembelajaran sehingga bagi peneliti lain hendaknya dapat mencarikan solusi pada perencanaan dan pelaksanaan pembelajaran kurikulum 2013 sehingga diharapkan dapat meningkatkan kualitas pendidikan demi kemajuan bangsa.

\section{DAFTAR RUJUKAN}

Agung, A. A. Gede. 2014. Metode Penelitian Pendidikan. Yogyakarta : Aditya Media Publishing.

Arikunto, Suharsimi dan Cepi Safrudin Abdul Jabar. 2008. Evaluasi Program Pendidikan. Jakarta: Bumi Aksara

Dewi, Metta Anugrah dkk. 2015 . "Diskrepansi

Pembelajaran Kurikulum 2013 Berdasarkan Permendikbud No. 65 Tahun 2013 Di
Sd No. 4 Kampung Baru". Undiksha, Volume 3, Nomor 1.Tersedia Pada http:// ejournal. undiksha.ac.id/index. php/JJPGSD/article/view/5734/4165 (diakses Pada tanggal 6 januari 2016).

Hadi, Samsul dan Mutrofin. 2005. Pengantar metode Riset Evaluasi.Yogyakarta: PT. Kurnia Kalam Semesta.

Suparno, dkk. 2002. Reformasi Pendidikan Sebuah Rekomendasi.Yogyakarta : Kasinus.

Syaefudin Sa'ud, Udin. 2010. Pengembangan Profesi Guru. Bandung : Alfabeta.

Undang-Undang Nomor 20 Tahun 2003 (UU 20/2003) tentang Sistem Pendidikan Nasional, tersedia pada http://kemenag.go.id/file/dokumen/UU20 03.pdf (diakses pada tanggal 15 nopember 2015).

Widnyani, Ni Kadek Sadewi dkk. 2015. "Diskrepansi Pembelajaran kurikulum 2013 berdasarkan Permendikbud Nomor 65 Tahun 2013 di SD Laboratorium Undiksha".Undiksha, Volume 3, Nomor 1. Tersedia pada http://ejournal.undiksha.ac.id/index.php/J JPGSD/article/viewFile/5154/3896(diakse s pada tanggal 15 nopember 2015).

Wirianto, Dicky. 2014. "Persepektif Historis Transformasi Kurikulum di Indonesia". Islamic Studies Jurnal, Volume 2,nomor 1. tersedia pada http://islamicstudiesjournal.com/index.ph p/component/joomdoc/islamic\% 20 studies $\% 20$ journal $\% 20$ Vol $\% 202 \% 20 \mathrm{~N}$ o.\%201\%20Januari-Juni\%202014/ 7\%20Dicky\%20Wirianto\%20Perspektif\% 20Historis\%20Transformasi\%20Kurikulu m\%20di\%20Indonesia.pdf/detail (diakses pada tanggal 15 nopember 2015) 